\title{
MEDIA BARU DAN KONFLIK POLITIK ISLAM DI INDONESIA
}

\author{
Siti Mupida \\ Pascasarjana Interdisciplinary Islamic Studies UIN Sunan Kalijaga Yogyakarta \\ Email:mufida260893@gmail.com
}

\begin{abstract}
Abstrak
Berangkat dari fenomena gerakan Islamis yang memberikan warna menonjol dalam dinamika politik Islam di Indonesia. Ideolog-ideolog aktif menggelar aksiaksi jihad dari berbagai kawasan konflik di Indonesia. Tulisan ini berupaya menjelaskan situasi politik Islam yang terefleksi dari media baru dan pandangan ulama mengenai negara-bangsa yang menunjukkan adanya beberapa gugatan dan konflik terhadap negara-bangsa tapi juga mencerminkan kompleksitas politik Islam dan terjangan globalisasi melalui media baru. Untuk menjawab pertanyaan tersebut, peneliti melakukan metode penelitian memalui fenomenologi dan kajian pustaka. Hasil dari studi ini menunjukkan bahwa gerakan-gerakan Islamis aktif memperkenalkan pemikiran yang berusaha mendefinisikan Islam sebagai ideologi politik. Sementara itu, media baru menjadi salah satu faktor yang signifikan dalam mempengaruhi dinamika dan manifestasi terbaru dari politik Islam di seluruh dunia. Tumbuhnya mode baru komunikasi yang interaktif, seperti televisi, internet dan telepon pintar, telah meningkatkan kapasitas dan ekspresi individu memahami konflik.
\end{abstract}

Kata kunci: media baru, konflik, politik Islam 


\section{Pendahuluan}

Dalam 25 tahun terakhir, perkembangan teknologi media luar biasa dahsyatnya dalam mengubah dunia digital, terutama dunia Islam. Semuanya serba tersambung antara komunitas satu dengan komunitas yang lain dan tidak ada lagi batasan, semuanya serba terdigitalisasi. Inilah yang kemudian menimbulkan konsekuensi di masyarakat, termasuk kehidupan politik, dan keagamaan umat Islam. Dinamika keagamaan berkembang begitu dahsyat, hal ini dapat dilihat dari terjadinya fragmentasi otoritas keagamaan, terjadinya mode-mode produksi pengetahuan keagamaan baru dan juga mendorong tampilnya new religious, new ulama, new audiens yang ikut serta meramaikan perdebatan tentang simbol-simbol agama.

Sebelumnya, kajian tentang otoritas keagamaan telah dibahas oleh Echchaibi yang memfokuskan tentang bagaimana otoritas keagamaan lokal mendapatkan pendengar baru di ruang lingkup transnasional. Studi ini mengeksplorasi tentang kesuksesan dakwah Amr Khaled, Moez Masoud dan Ali Ardekani, yang menembus batas tradisional Mesir dan Arab Saudi, hingga ke Dubai, London, Paris dan Los Angeles melalui rekaman audio blog. ${ }^{1}$ (Echchaibi, 2011: 30). Di samping itu, penelitian terbaru mengenai otoritas ulama, telah dibahas oleh Mufida dan Shalihati yang mengkaji lebih jauh

1 Nabil Echchaibi, "From Audio Tapes to Video Blogs: The Delocalisation of Authority in Islam: From Audio Tapes to Video Blogs," Nations and Nationalism, Vol. 17, No. 1 (2011), 25-44. tentang otoritas keagamaan yang diperoleh Salim A. Fillah melalui dakwah by the pen.Konstribusi tulisannya pada perkembangan eksplorasi otoritas keagamaan melalui karya Islami dalam praktik kehidupan komunitas Muslim di Indonesia. $^{2}$

Tulisan ini akan memotret bagaimana peran media baru dalam fragmentasi politik Islam di dunia, khususnya Indonesia. Dengan adanya peran teknologi digital ini, memberikan pengaruh yang signifikan terhadap kaum muda, terutama dalam hal keagamaan. Dengan adanya media baru, akan terlihat bagaimana masyarakat dan kaum muda dalam mempersepsikan konflik politik Islam dan mengkontekstualisasikan keagamaan. Untuk itu, perlu adanya pendidikan dan ekspansi dalam menghadapi new media dan berbagai konflik pilitik Islam.

Media baru atau internet membawa nilai baru dalam beragama bagi sebagian masyarakat. Sehingga dengan kehadiran media baru tersebut sebagain orang cenderung mengambil nilai agama melalui media. Sebagai contoh adalah dengan berkembanganya media online yang menggunakan pendekatan Islam. Media ini menggunakan content yang memiliki corak ajaran Islam. Bahkan seseorang yang ingin mencari referensi al Qur"an dan hadis hanya perlu mengklik sebuah situs online, maka referensi yang dicari akan

2 Siti Mupida dan Khoirin Nisai Shalihati, "Dakwah by The Pen: Salim A. Fillah"s Authority in Pro U Media," Interdisciplinary Journal of Communication, Vol. 4, No. 1 (2019), 35-44. 
muncul. Media sosial merupakan istilah umum yang digunakan untuk berinteraksi dengan sesama manusia yang mencakup platform online dengan berbagai atribut, format dan unsur dalam komunikasi. Media sosial menjadi begitu menarik karena memiliki berbagai unsur dan karakter, sehingga memberi pengaruh yang signifikan pada beberapa aspek di kehidupan dunia nyata, termasuk memberikan stimulasi gerakan sosial. ${ }^{3}$

Hampir secara keseluruhan masyarat mencari sumber hukum agama atau dasar teologi dari media baru (teologi on new media). Kondisi tersebut semakin terlihat nyata dengan munculnya internet atau yang disebut dengan media baru (new media). Media baru (internet) juga berfungsi sebagai entitas untuk menyebarkan ajaran agama. Jika dahulu seseorang yang ingin menyebarkan agama harus menempuh dengan jalan kaki, maka sangat berbeda dengan saat ini. Media baru (internet) sudah menyediakan ruang bagi setiap orang, kelompok maupun lembaga yang akan menyebarkan agama. Dengan menggunakan situs online maka seseorang dapat membuat progam penyebaran berupa content keagamaan. Content yang dibuat tersebut menembus batas ruang, waktu dan berbagai kalangan.

Sebagai contoh dapat kita lihat pada penggunan media online atau youtube dalam menyebarkan berbagai video dakwah Islam. Jika

\footnotetext{
${ }^{3}$ Iswandi Syahputra, "Media Sosial dan Prospek Muslim Kosmopolitan; Konstruksi dan Peran Masyarakat Siber Pada Aksi Bela Islam,"Jurnal Komunikasi Islam, Vol. 08, No. 01, (2018), 20.
}

zaman dahulu ceramah atau dakwah dilakukan dengan ceramah dari mimbar ke mimbar, maka sekarang cara tersebut dianggap tidak efektif lagi. Penyebaran dakwah dan agama Islam dianggap lebih efektif dengan memanfaatkan media baru atau internet. Selain itu, hasilnya dapat dilihat oleh orang lain dengan jumlah yang tidak terbatas. Penyebaran dakwah melalui internet ini tidak dibatasi oleh ruang dan jarak, bahkan dalam hitungan detik dapat dijangkau. Hal tersebut menunjukkan bahwa agama dan media memiliki hubungan yang sangat signifikan.

Tulisan ini akan mendiskusikan tentang pengaruh media baru terhadap konflik politik Islam yang dilihat dari spektrum lebih luas. Dinamika politik tidak pernah berhenti di negeri ini. Selalu ada permasalahan dan konflik, kekerasan, terorisme, hingga perang ideologi yang selalu dikaitkan dengan agama. Secara spesifik artikel ini akan merujuk pada beberapa gerakan dan aksi jihad Muslim yang ingin membangun politik Islam di Indonesia.

\section{Agama dan Media Baru}

Kehadiran media sosial yang dijadikan sebagai sumber informasi oleh khalayak memberikan pengaruh yang signifikan terhadap pola interaksi antar individu bahkan kelompok dalam menggunakan media baru. Tidak jarang sebagian khalayak mencari sumber informasi hukum dan agama melalui media baru(new media).

Dakwah sebagai media pembentuk kepribadian (self personality) dan perilaku (attitude) umat harus dihadirkan dengan strategi yang berhaluan kepada 
pengembangan keberagamaan (religiosity) yang progresif. Progresivitas dakwah mustahil diwujudkan tanpa dukungan media dan strategi dakwah yang kompeten. Seiring dengan munculnya ragam media dan strategi dakwah, eksistensi jurnalistik hadir sebagai salah satu media komunikasi produktif. Di samping strategi dakwah yang telah umum diterima akal sehat, kehadiran jurnalistik menjadi media kontemporer yang dapat menyeimbangi perkembangan zaman (globalization) yang semakin pesat. Kehadiran media jurnalistik dalam dinamika kehidupan manusia menjadi fakta yang tidak terelakkan. Televisi dan media teknologi informasi lainnya jelas memainkan peran penting dalam memfasilitasi kegiatan keagamaan di Indonesia. ${ }^{4}$

Media dan agama memang memiliki relevanasi yang cukup siginifikan. Namun, media tetap tidak dapat dijadikan sebagai agama apapun. Media hanya dapat dijadikan sebagai wasilah atau saluran dalam penyebaran agama (dakwah). Namun, praktik keagamaan harus dikembalikan pada kitab suci yang dimiliki oleh agama tersebut. Sehingga, agama bukan merupakan produk budaya media. Agama dan media memiliki hubungan timbal balik dalam setiap sejarah kehidupan manusia.

Budaya media dengan segala konsekuensi pengaruh baik dan

${ }^{4}$ Akh Muzakki, "Islam as a Symbolic Commodity: Transmitting and Consuming Islam Through Public Sermons in Indonesia," dalam Pattana Kitiarsa (ed.), Religious Commodifications in Asia: Marketing Gods (London dan NewYork: Routledge, 2008), 207. buruk yang ditimbulkan, merupakan suatu pengaruh atau efek dari media itu sendiri. Sebab dalam dunia modern, arus informasi yang bertebaran di sekitar kita hanya membawa dua pilihan, ambil atau tinggalkan. Bahkan pada tahapan paling ekstrim, rutinitas keagamaan bisa terganggu oleh derasnya arus informasi yang dihasilkan oleh budaya media. Peran agama yang sesungguhnya adalah membuat orang sadar akan fakta. ${ }^{5}$ Ada ketergantungan yang nyata, antara kebutuhan terhadap informasi dengan pengaruh yang timbul akibat kecemasan terhadap media. Dalam kehidupan beragama, mau tidak mau atau suka tidak suka harus menyesuaikan diri dalam menyikapi terjadinya perubahan yang cepat dalam perkembangan arus informasi yang terjadi pada budaya media. Sebab, bersikap menghindar hanya akan membuat kualitas manusia beragama tertinggal dalam segala hal. ${ }^{6}$

Menilik pada aksi bela Islam yang dikenal sebagai aksi 212 pada 2 Desember 2018 dalam liputan di banyak media (baik media mainstream yang sekuler maupun media-media komunitas di kalangan kaum Muslim yang beragam) diapresiasi sebagai aksi damai. Hal itu dikarenakan aksi tersebut ditunjukkan melalui suatu mobilisasi massa yang demikian besar dalam

\footnotetext{
${ }^{5}$ Ahfa Waid, Nasihat-Nasihat Keseharian Gus Dur, Gus Mus, dan Cak Nun,(Yogyakarta: DIVA Press, 2017), 4246.

6 Lihat artikel Siti Mupida, http://swarakampus.com/web/2018/11/02/ag ama-dan-media-baru/
} 
bentuk ibadah shalat Jum at di lapangan Monas, Jakarta pada 2 Desember 2016. Kasus „Aksi Bela Islame pada tahun 2016 menuntut Gubernur DKI Jakarta, Basuki Tjahaja Purnama, atau yang biasa dikenal dengan nama Ahok, dipenjara karena dianggap telah menista Islam. Kasus ini menunjukkan bahwa para penyelenggara aksi telah berhasil memobilisasi dukungan massa melalui kampanye di media sosial.

Aksi ini berasal dari berbagai gerakan, seperti gerakan Salafi, Hizbut Tahrir Indonesia. Sebelum memahami bagaimana gerakan Wahhabi-Salafi di Indonesia, perlu memahami gerakan-gerakan yang dianggap radikal. Bagi masyarakat di Indonesia, gerakan Islam yang paling familiar di telinga adalah gerakan Nahdatul Ulama (NU), Muhammadiyah. Namun belakangan ini, masyarakat Indonesia mulai terbiasa mendengar gerakan seperti Wahhabi, Salafi, dan Hizbut Tahrir Indonesia (HTI). Sebagian masyarakat memahami bahwa gerakan-gerakan ini memiliki kemiripan, namun pada dasarnya gerakan ini memiliki banyak perbedaan. Gerakan ini disebut sebagai gerkan transnasional. Masuknya gerakan Islam transnasional sering dianggap sebagai suatu ,ancaman ${ }^{\text {ce }}$ oleh beberapa pihak maupun kelompok tertentu. Paham seperti ini sudah mulai tumbuh subur dan berkembang, bahkan dituding sebagai akar dari aksi Islam yang puritan di Indonesia, serta dianggap sebagai gerakan yang radikal. Para peneliti telah mengkaji beberapa aksi jihad di Indonesia yang bertujan ingin membangun Islam yang kaffah, dan bebas dari unsur syirik dan bid"eah.

Di samping itu, kajian mengenai Aksi Damai 411-212 dan Kesalehan Polpuler, dan Identitas Muslim Perkotaan di Indonesia oleh Muhammad Wildan. Dalam penelitiannya, Wildan mengkaji aksi bela Islam 411 dan 212 dengan melihat dari perspektif budaya populer. ${ }^{7}$ Tidak sedikit dari pengamat dan para akademisi yang cenderung melihat demonstrasi jutaan Muslim ini sebagai puncak dari merebaknya konservatisme di Indonesia. Namun, dapat kita lihat berbagai aksi dari mahasiswa terhadap ketidakpuasan terhadap sistem pemerintahan di Indonesia. Aksi tersebut berupa demonstrasi yang dilakukan oleh beberapa kampus di Indonesia tolak hasil revisi undang-undang.

Demokratisasi menjadi tuntuntan utama bagi gerakan reformasi di Indonesia yang membuka ruang publik baru bagi aktor-aktor politik, sosial dan bahkan keagamaan untuk merepresentasikan kembali formulasi kemaslahatan negara-bangsa dalam menghadapi krisis ekonomi dan politik. Selain aktor politik maupun pemerintah, akademisi, ulama dan tokoh agama juga berperan aktif guna mengonseptualisasikan kemaslahatan bangsa Indonesia dalam spektrum yang beragam. Karena banyak cara dilakukan oleh partai politik untuk menarik simpati warga kampus,

${ }^{7}$ Muhammad Wildan, "Aksi Damai 411-212 dan Kesalehan Polpuler, dan Identitas Muslim Perkotaan di Indonesia", Maarif Institute for Culture and Humanity, Vol. 11. No 2, (2016), 188-190. 
terutama mahasiswa. Kendati universitas adalah salah satu zona larangan kampanye, bukan berarti kampus bebas dari aktivitas politik. Istilah ilmu politik (political science) pertama kali digunakan oleh Jean Bodin di Eropa pada tahun 1576, dalam pandanganya ilmu politik sebagai ilmu negara bukan lagi dalam pengertian institusi yang statis, tetapi lebih maju dengan melihat negara sebagai lembaga politik yang mempengaruhi kehidupan masyarakat. ${ }^{8}$

Dalam kehidupan sehari-hari istilah "politik" sudah tidak begitu asing, karena segala sesuatu yang dilakukan atas dasar kepentingan kelompok atau kekuasaan sering kali di atas namakan dengan label politik. Bahkan beberapa mata kuliah sering dikaitkan dengan politik di lingkungan kampus. Kajian Michael Foucault tentang ,relasi kekuasaan bisa membantu untuk menentukan hubungan kampus dan politik. Menurut Foucault, kekuasaan "politik" pada dasarnya tidak melembaga hanya pada satu muka (seperti lembaga pemerintahan atau partai politik), tetapi menyebar melalui relasi-relasi yang bersifat diskursif dan abstrak. ${ }^{9}$

Selain itu, ruang lingkup dunia kampus selalu aktif dalam dinamika politik. Hal ini bisa dilihat dari berbagai konflik politik yang terjadi antara mahasiswa dan pemerintah.

Seperti konflik demo tentang penolakan terhadap hasil revisi

\footnotetext{
${ }^{8}$ Hafied Cangara, Komunikasi Politik, Konsep, Teori, dan Strategi,(Depok: Rajawali, 2016), 95-101.

9 James Faubion. 1994. Aesthetics, Method, And Epistemology,(New York: The New Press, 1994), 26-35.
}

Rancangan Kitab Undang-Undang Hukum Pidana (RKUHP) yang berkelanjutan pada pertengahan bulan September 2019 dilakukan oleh beberapa kampus di Indonesia, misal Universitas Gajah Mada dan mahasiswa Universitas Trisakti, dan kampus lainnya. Dari konflik tersebut ada beberapa di antaranya dapat diselesaikan, akan tetapi ada juga beberapa di antaranya yang tidak dapat diselesaikan sehingga menimbulkan beberapa aksi kekerasan. Untuk itu, peranan kampus, akademisi, dan paradigma komunikasi berperan penting dalam menangani resolusi konflik yang terjadi di dunia politik. ${ }^{10}$

Situasi yang dihadapi oleh Indonesia saat ini, sebagaimana terefleksi pandangan dan persepsi ulama mengenai negara-bangsa, tidak saja menunjukkan masih adanya beberapa gugatan dan ketidaknyamanan terhadap negarabangsa, akan tetapi juga mencerminkan kompleksitas politik Islam (Muslim politics) yang berkembang di tengah arus deras perubahan sosial dan terjangan globalisasi. ${ }^{11}$ Hal ini dibuktikan dengan hadirnya simbol-simbol Islam di arena politik, di tengah berkembangnya politik identitas.

\section{Penyebaran Ideologi Ultra- Konservatif di Media Sosial}

Dalam 20 tahun terakhir, dunia menyaksikan perkembangan

10 Lihat Artikel Siti Mupida. http://swarakampus.com/web/2019/09/29/pe ran-politik-kampus/

11 Noorhaidi Hasan, "Tantangan Islam Politik dan Krisis Legitimasi Ulama," dalam Noorhaidi Hasan, Ulama dan NegaraBangsa Membaca Masa Depan Politik Islam di Indonesia, (Yogyakarta:PusPIDep, 2019), 47-52. 
teknologi komunikasi dan informasi yang dahsyat. Salah satu konsekuensinya adalah teknologi digital yang telah merasuki kehidupan kita. Misal ketika kita bangun pagi hal pertama yang kita ingat dan ambil adalah smartphone. Kemanapun kita pergi, kita selalu membawa smartphone dan mengeceknya hampir setiap jam atau bahkan menit. Hal ini membuat kita menjadi ketergantungan dengan media digital. Bahkan ketika melakukan ibadah haji atau umroh, sebagian orang melakukan selfie, kemudian mengunggah di facebook, instagran, dan whatsApp. Namun, paradoksnya ekspansi teknologi digital tidak serta-merta menghadirkan pluralisme sipil. Dalam beberapa kasus teknologi digital memungkinkan banyak hal buruk yang terjadi termasuk penyebaran konservatisme, radikalisme, dan terorisme.

Berbagai strategi dilakukan oleh kelompok radikal untuk melakukan propaganda dan penyebaran isu terorisme. Mulai dari penyebaran paham radikal secarang langsung maupun sembunyisembunyi hingga menggunakan aplikasi media sosial dan pesan instan. Kecepatan serta kemudahan akses informasi membuat media sosial semakin efektif dalam membuat konten radikal secara mudah dan masif. Beredarnya konten radikal ini di media sosial, menjadi „ancaman ${ }^{\text {ee }}$ yang serius bagi masyarakat Indonesia yang sangat akrab dengan media sosial. Salah satu aplikasi yang digunakan untuk penyebaran informasi radikal adalah "telegram",Instagran, dan whatsapp.aplikasi telegram ini telah berkeembang selama empat tiga tahun terakhir. Pada perkembangannya, telegram diduga digunakan sebagai media komunikasi oleh kelompok radikal. Menutut media institude ISIS mengklaim menggunakan aplikasi media telegram untuk bertukar informasi termasuk tutorial membuat senjata hingga meluncurkan serangan cyber.

Pada dasarnya, media sosial mempunyai peran penting dalam memberikan informasi ke publik terkait isu radikalisme, sehingga publik terpropaganda terhadap isuisu radikal yang disebarkan melalui media baru. Fauzi Ghifari telah membaahas isu mengenai Radikalisme di Internet. Dalam penelitiannya, Fauzi Ghifari mendiskusikan bahwa, terdapat sejumlah kelompok teroris yang menggunakan media sosial sebagai media dakwah dan membangun situs khusus sebagai medium untuk mengkoordinasikan semua kegiatan yang berkaitan dengan radikalisme dan terorisme. Fauzi Ghifari menegaskan ada tiga tahapana perkembangan dan pola penyebaran paham radikalisme maupun terorisme di dunia cyber.Pertama, pada tahap awal hanya berupa penyebaran ideologi melalui fasilitas website. Kedua, pemanfaatan fitur media interaksi seperti pembuatan forums dan chatrooms.Ketiga, penggunaan new media seperti youtube, telegram,facebook, dan twitter yang semakin populer di generasi milenial. ${ }^{12}$

Menurut penulis, radikalisme memiliki keterkaitan dengan

\footnotetext{
${ }^{12}$ Iman Fauzi Ghifari, "Radikalisme di Internet", Jurnal Agama dan Lintas Budaya, Vol. 1, No. 2, (2017), 123-124.
} 
terorisme, keduanya merupakan tindakan kekerasan atau ,ancaman bagi kehidupan manusia. Tindak kejahatan tersebut sesungguhnya dilakukan oleh sekelompok minoritas yag menolak dan sekaligus tidak percaya lagi dengan sistem demokrasi yang ada. Dengan kata lain, tindakan mereka yang mengatasnamakan „Islame merupakan bentuk ketidakpuasan terhadap pemerintah.

Dalam penelitian ini, penulis akan mengeksplorasikan beberapa kajian terkait dengan penyebaran ideologi ultra-konservatif. Van Bruinessen mendefinisikan Islam konservatif sebagai ,berbagai aliran pemikiran yang menolak penafsiran ulang atas ajaran-ajaran Islam secra liberal dan progresif, cenderung untuk mempertahankan tafsir dan sistem sosial yang baku". ${ }^{13}$ Pada dasarnya, gerakan Islam konservatif bertolakbelakang dari Islam liberal atau Islam progesif yang diartikan sebagai suatu gerakan yang mendukung gagasan untuk menafsirkan kembali ajaran Islam secra kontektual. Sejatinya, Islam konservatif berbeda dengan Islam fundamentalis, yakni gerakan atau aliran yang mengajak kembali pada Islam puritan, yakni berdasarkan sumber ajaran Islam Alquran dan hadis. Gerakan konservatif juga berbeda dengan gerakan „Islamis ${ }^{\text {ee }}$ yang didefinisikan sebagai suatu gerakan yang mendukung gagasan Islam sebagai sebuah sistem politik

13 Martin van Bruinessen, ed, Contemporary Development in Indonesian Islam, Explain the „Conservative Turn", (Singapore: Institute of Southeast Asian Studies, 2013). 16. dan berjuang untuk mendirikan negara Islam yang kaffah. ${ }^{14}$

Van Bruinessen dalam kajiannya memberikan penjelasan mengenai argumen mengapa konservatisme muncul kembali di Indonesia. Pertama, argumen yang menegaskan bahwa manyoritas umat Islam Indonesia pada dasarnya konservatif atau cenderung mempunyai corak Islam fundamentalis. Hal ini dapat diliht dari proses hubungan antara demokratisasi dan memudarnya pengaruh pandangan-pandangan Islam yang liberal dan progresif. Kedua, menguatnya pengaruh dari Timur Tengah. Kajian mengenai menguatnya pengaruh Timur Tengah di Indonesia telah dikaji oleh Noorhaidi Hasan. ${ }^{15}$ Para alumni dari Timur Tengah menyebarkan dan mendakwahkan corak pemahaman keislaman yang skipturalis kepada masyarakat dengan berbagai cara. Cara tersebut berupa mengadakan pengajian di masjid-masjid, mendirikan pesantren, televisi dakwah, dan dan menerbitkan bukubuku dan majalah keislaman. Alumni ini melakukan kerjasama dengan lulusan Lembaga Ilmu Pengetahuan Arab dan Islam (LIPIA) di Jakarta.

Di samping itu, kajian selanjutnya yang ditulis oleh Ahmad Najib Burhani yang mendiskusikan dinamika pemikiran keislaman di tubuh Muhammadiyah. Burhani

\footnotetext{
Din Wahid, "Kembalinya Konservatisme Islam Indonesia", Studia Islamika, Vol. 21, No, 2, (2014), 377-385.

15 Noorhaidi Hasan, Laskar Jihad, Islam, Militancy and the Quest for Identity in Post New Order Indonesia, (New York: Cornell Southeast Asia Program, 2016), 4144.
} 
menjelaskan bahwa menguatnya gejala konservatisme di dalam tubuh ormas Muhammadiyah. ${ }^{16}$ Argumen utama kajian ini bahwa kecenderungan konservatisme yang terdapat dalam muktamar Muhammadiyah ke-45 bukan merupakan karakter utama Muhammadiyah. Karena kecenderungan tersebut lebih disebabkan oleh faktor luar, yakni perkembangan politik nasional dan munculnya berbagai gerakan Islam transnasional.

Munculnya gerakan Islam transnasional tentu tidak terjadi secara instan. Gerakan-gerakan ini mempunyai jaringan yang kuat di seluruh dunia. Di samping itu, masuknya gerakan Islam transnasional sering dianggap sebagai suatu ancaman oleh beberapa pihak maupun kelompok tertentu. Paham seperti ini sudah mulai tumbuh subur dan berkembang, bahkan dituding sebagai akar dari aksi Islam yang puritan di Indonesia, serta dianggap sebagai gerakan yang radikal. Radikalisme sering diidentikkan dengan terorisme yang menuju pada Islam. Gerakan ini awalnya muncul sebagai bentuk perlawanan komunisme di Indonesia, serta perlawanan terhadap penerapan Pancasila sebagai asas tunggal dalam politik. Karena bagi kaum radikalis yang menginkan formaliasi hukum syariah sebagai solusi dalam kehidupan bernegara tanpa menganut asas demokrasi. ${ }^{17}$ Bagi masyarakat di

${ }^{16}$ Ahmad Najib Burhani, "Pluralism, Liberalism and Islamism: Religious Outlook of Muhammadiyah", Studia Islamika, Vol. 25, No. 3 (2018). 439-446.

17 Zuly Qodir, "Gerakan Salafi Radikal dalam Konteks Islam Indonesia:
Indonesia, gerakan Islam yang paling familiar di telinga adalah gerakan Nahdatul Ulama (NU), Muhammadiyah. Namun belakangan ini, masyarakat Indonesia mulai terbiasa mendengar gerakan seperti Wahhabi, Salafi, dan Hizbut Tahrir Indonesia (HTI). Sebagian masyarakat memahami bahwa gerakan-gerakan ini memiliki kemiripan, namun pada dasarnya gerakan ini memiliki banyak perbedaan.

Kajian selanjutnya, yaitu tentang ,gerakan Islam radikal di Soloe oleh Muhammad Wildan. Wildan berusaha untuk memetakan gerakan Islam radikal di Solo yang tumbuh subur, meskipun mayoritas masyarakat Solo adalah abangan, dengan corak keberagaman yang sinkretis, akan tetapi kota Solo juga dikenal sebagai salah satu kota yang penuh dengan gejolak gerakan Islam. ${ }^{18}$ Dalam pandangan Wildan yang pernah mengenyam pendidikan di Ngruki, pesantren Ngruki tidak lepas dari sorotan penelitiannya. Ngruki didirikan oleh aktivis Islam, yakni Abdullah Sungkar dan Abu Bakar Baasyir. Pesantren Ngruki dianggap telah menyebarkan ideologi radikal yang bisa berkembang dikemudian hari. Hal ini terbukti dari beberapa alumni pondok Ngruki yang terlibat dalam tindakan kekerasan termasuk terorisme, bahkan pimpinan pondok Ngruki tersebut, yakni Abdullah Sungkar dan Abu Bakar Baasyir pernah

Tinjauan Sejarah", ISLAMIKA, Vol. 1, No. 8 (2008). 3-15.

18 Muhammad Wildan, "The Nature of Radical Islamic Groups in Solo", Journal of Indonesia Islam, Vol. 07, No. 01, (2013). 50-58. 
ditahan dan dipenjarakan oleh pemerintah. Salah satu penyebab maraknya gerakan Islam radikal di Solo adalah peran dan pengaruh dua ormas terbesar, yaitu Nahdatul Ulama (NU) dan Muhammadiyah yang sangat kecil.

\section{Politik}

Resolusi Konflik Islam

Dalam setiap kehidupan sosial tidak ada satu pun manusia yang memiliki unsur-unsur kesamaan hidup, ideologi, dan sudut pandang satu sama lain. Persamaan dan perbedaan yang terdapat dalam kehidupan manusia tercermin dalam bentuk diferensiasi antar kelompok yang berdasarkan atas unsur etnis, kepentingan, kemauan, kehendak, dan tujuan. Penulis melihat bahwa setiap konflik tersebut ada beberapa diantaranya dapat diselesaikan dan ada juga konflik yang tidak dapat diselesaikan, sehingga menimbulkan beberapa aksi kekerasan. Kekerasan merupakan gejala di mana gejala tersebut menyebabkan timbulnya konflik yang tidak dapat teratasi sehingga menimbulkan kekerasan, mulai dari kekerasan terkecil hingga peperangan.

Dalam konflik ideologis, konflik tersebut muncul dalam perbedaan persepsi dari berbagai golongan masyarakat dalam menyikapi satu persoalan. Sementara pada tingkat politis, konflik terjadi disebabkan karena adanya pertentangan dalam pembagian sumber kekuasaan. Walaupun demikian, tidak menutup kemungkinan bahwa konflik yang ada dalam masyarakat Indonesia dapat dimanimalisir dengan penyelesaian konflik secara konstruktif (resolusi konflik). ${ }^{19}$

Pada dasarnya, penyebab konflk politik dapat dibedakan dalam dua aspek. Pertama, dilihat dari aspek kemajemukaan harizontal, artinya struktur masyarakat yang majemuk secara kultural, seperti suku bangsa, daerah, agama, ras, dan majemuk secara sosial dalam perbedaan pekerjaan maupun profesi. Kedua, kemajemukan secara vertikal, artinya struktur masyarakat yang terpolarisasi secara hierarkis (dalam ketidaksederajatan) yang didasarkan pada keberadaan kekayaan, pendidikan, kekuasan, dan sebagainya. ${ }^{20}$

Narasi radikalisme melalui media sosial mengenai Islam politik di Indonesia perlu dipahami secara signifikan. Pada dasarnya, media sosial bertujuan untuk mempermudah manusia berinteraksi dan mengakses informasi lebih cepat. Namun, beberapa kelompok menyalahgunakan media sosial sebagai sarana untuk menyebarluaskan berita hoax, Di era generasi milenial ini, media sosial menjadi alat dan sarana penebar kebohongan dan informasi hoax. Sehingga masyarakat menjadi sasaran empuk untuk pertukaran informasi hoax. Tanpa mencari dengan teliti kebenaran suatu informasi. Hal inilah yang menjadi penyebab menyebarnya informasi hoax dengan cepat melalui media

\footnotetext{
19 Jakiatin Nisa, "Resolusi Konflik dalam Perspektif Komunikasi”, Jurnal Sosial dan Budaya Syar"i, Vol. II, No. 1 (2015), 28-29.

${ }^{20}$ Elly M. Setiadi \& Usman Kolip, Pengantar Sosiologi Politik, (Jakarta: Prenada Media Group, 2013), 59-61.
} 
sosial. Kebenaran suatu informasi tidak lagi menjadi hal penting bagi pelaku hoax demi memenuhi kepuasaan dan hasrat duniawi tanpa memikirkan effect buruk yang ditibulkan. ${ }^{21}$ Ada beberapa teori yang dapat menjadi acuan untuk melihat keperkasaan media maupun kelemahannya dalam mempersuasi masyarakan serta korelasi dengan aktivitas politik yaitu, teori jarum suntik. Teori jarum suntik berpendapat bahwa khalayak maupun masyarakat sama sekali tidak memiliki kekuatan untuk menolak suatu informasi setelah ditembakkan melalui media komunikasi. Masyarakat terlena seperti kemasukan obat bius melalui jarum suntik, sehingga tanpa sadar akan pentingnya kebenaran suatu informasi.

Di samping itu, dalam memahami politik Islam terdapat beberapa kelompok atau gerakan yang memanfaatkan media baru untuk menyebarluaskan paham radikalisme. Misalnya, pada tahun 2015, Bahrun Naim yang merupakan salah satu dari anggota gerakan yang pro-ISIS memulai memposting intruksi pembuatan bom di blogpribadinya;

http://innamadunyafanaa.blogspot.co

.id. Blog tersebut telah ribuan kali dibanned dan muncul kembali dengan nama baru, termasuk salah satunya www.bahrunnaim.co yang diilhami oleh majalah Inspire ISIS dan pembelajaran „e-jihad ${ }^{e e}$, di mana Bahrun Naim meyakini bahwa seseorang tidak perlu pergi ke luar negeri untuk mempelajari dasar-

21 Lihat Artikel Siti Mupida, http://swarakampus.com/web/2018/10/15/be rita-hoax-memecah-belah-masyarakat/\# dasar ilmu kemiliteran. Bahrun Naim berharap pendukung ISIS di Indonesia yang ingin ikut ambil bagian dalam aksi jihad, termotivasi oleh ketersediaan bahan-bahan artikel bacaan di blog-nya, Bahrun Nain juga menyusun semua konten menjadi e-book yang tetap dapat digunakan setelah kematiannya. Bahrun Naim bahkan juga membuka konsultasi online tentang cara merakit bom. $^{22}$

Sebelum memahami bagaimana pengaruh ISIS di Indonesia, perlu terlebih dahulu memahami makna ISIS yang sebenarnya, yaitu berawal dari sebuah deklarasi „khalifah ${ }^{\text {ee }}$ yang digagas oleh Abu Bakr al Bagdadi pada Oktober 2014, yang dikenal sebagai Negara Islam (sebelum dikenal dengan nama Negara Islam Irak dan Suriah atau ISIS) adalah kelompok organisasi jihad yang mempunyai tujuan untuk membentuk sebuah Negara Islam di wilayah Irak dan Suriah. Sejak kemunculannya, pergerakan ISIS ini memiliki ideologi ekstrim, sehingga hal ini dapat memberikan ancaman atau teror kepada masyarakat dan disertai dengan beberapa pelanggaran aksi kekerasan dalam membentuk Negara Islam.

Tulisan ini menawarkan beberapa pendekatan dalam resolusi konflik. Pertama, menjauhi, artinya menghindar dari konflik itu sendiri. Kedua, edukasi dan kontak, artinya konflik dihadapi melalui pendidikan dan komunikasi (pendekatan ini dianggap paling elegan). Ketiga, remisi spontan, artinya yang

22 IPAC Report No 56, (2019), "The Ongoing Problem of Pro-ISIS Cells in Indonesia", 2-5. 
bersangkutan tiba-tiba menganggap konflik tersebut hilang atau efeknya berakhir. Keempat, negosiasi langsung, artinya dilakukan oleh pihak yang bertikai. Ini merupakan salah satu proses pengambilan keputusan melalui proses memberi dan menerima pendapat atau pandangan yang berbeda. Kelima, abitrase, artinya ketika dua orang yang berkonflik kemudian menyerahkan persoalan kepada pihak ketiga, selanjutnya keputusan berada pada pihak ketiga.

Munculnya berbagai gejala sosial termasuk gejala politik dalam hubungan antar kehidupan bermasyarakat, perlu adanya pemahaman terhadap literasi-literasi sosiologi politik yang membahas mengenai berbagai cara dan pendekatan resolusi konflik yang terjadi dalam dunia politik. Pengetahuan dan literasi tersebut tidak hanya sekedar memotret gejala dan fakta sosial, tetapi harus melihat bagaimana fakta tersebut berkontribusi bagi kehidupan dan sistem demokrasi yang lebih baik untuk Indonesia.

Proses politik sesungguhnya merupakan proses penyelesaian konflik dalam suatu masyarakat atau negara. Proses penyelesaian konflik ini dapat diselesaikan melalui tiga tahap. Pertama, tahap politisasi dan koalisi, artinya agar tuntutan dari masyarakat mendapatkan perhatian dari pemerintah, maka masingmasing pihak yang terlibat dalam konflik akan berusaha mengadakan politisasi, yaitu memasyarakatkan tuntutannya melalui berbagai media massa sehingga menjadi issue politic. Kedua, tahap pembuatan keputusan, dalam hal ini ada dua kemungkinan sikap pembuat keputusan politik dalam menanggapi tuntutan dari berbagai kelompok yang ada dalam masyarakat, yaitu menolak tuntutan masyarakat dengan beberapa alasan tertentu dan menerima tuntutan kelompok masyarakat, baik secara tuntas maupun secara marginal. Ketiga, tahap pelaksanaan dan itegrasi, karena keputusan tanpa adanya pelaksanaan, maka tidak akan dapat menyelesaikan konfik dalam masyarakat. Birokrasi memainkan peranan utama dalam proses pelaksanaan keputusan tersebut.

Tulisan ini telah menyoroti wacana mengenai situasi politik Islam yang terefleksi dari media baru dan pandangan ulama maupun pihak akademisi mengenai negara-bangsa yang menunjukkan adanya beberapa gugatan dan konflik terhadap negarabangsa tapi juga mencerminkan kompleksitas politik Islam dan terjangan globalisasi melalui media baru. Di sisi lain, lebih dipilih menjadi alternatif yang cukup efektif untuk mendapatkan isu-isu update terkini. Hal ini didukung oleh pernyataan bahwa generasi milenial lebih suka memilih akses mudah melalui smartphone dan internet dalam mencari dan mempelajari segala hal termasuk dalam belajar ilmu agama. Ini merupakan salah satu dari kontribusi penulis dalam tulisan ini menunjukkan bahwa gerakan-gerakan Islamis aktif memperkenalkan pemikiran yang berusaha mendefinisikan Islam sebagai ideologi politik.

Aktor organisasi-organisasi radikal dan militan sangat pintar dalam memanfaatkan teknologi digital untuk menyebarkan ide dan ideologi mereka. Akibatnya platform 
media kita dipenuhi dengan ujaran kebencian, permusuhan, dan wacana kekerasan. Patut dicatat, bahwa kaum muda menjadi target utama kampanye mereka. Faktanya, kaum muda bertindak sebagai tulang punggung organisasi semacam itu. Akan tetapi, kaum muda juga memainkan peran penting sebagai inisiator trend global. Sementara, merasa tidak aman berhadapan dengan berbagai perubahan yang begitu cepat akibat globalisasi. Kaum muda dipaksa untuk mengklaim ruang dan mengkonsolidasikan identitas mereka.

\section{Kesimpulan}

Penulis penyadari bahwa, tidak bisa dipungkiri arus globalisasi dan kemajuan teknologi informasi memberi pengaruh yang signifikan terhadap pola interaksi sosial manusia. Paham radikalisme dan paham ekstrimisme menyebar dan berkembang dengan pesat. Media sosial atau new media merupakan media paling rawan untuk penyebaran ideologi ultra-konservatif seperti ISIS. Gerakan-gerakan ultrakonservatif tersebut menyebarkan ideologi (propaganda) mereka khususnya ke generasi muda dengan narasi-narasi extrimisme dan radikalisme. Berdasarkan pengamatan dan penelitian penulis, ideologi yang dikembangkan oleh gerakan-gerakan extrimisme adalah seputar narasi hijrah, jihad, khilafah, dan intoleren. Studi ini menunjukkan bahwa gerakan-gerakan Islamis aktif memperkenalkan narasi-narasi yang berusaha mendefinisikan Islam sebagai ideologi politik, bukan berdasarkan sistem demokrasi. Berkembangnya budaya digital atau new media, mendorong pergeseran minat dan pola generasi muda dalam mecari literatur-literatur keislaman. Tak sedikit dari kaum muda yang mengakses sumber pengetahuan keislaman melalui new media atau internet seperti, facebook, telegram, youtube, instagram, whatsapp melalui aplikasi smartphone.

\section{Daftar Pustaka}

Cangara Hafied. 2016. Komunikasi Politik, Konsep, Teori, dan Strategi. Depok: Rajawali.

Echchaibi Nabil. "From Audio Tapes to Video Blogs: The Delocalisation of Authority in Islam: From Audio Tapes to Video Blogs", Nations and Nationalism. Vol. 17, No. 1 (2011).

Fauzi Ghifari Iman. "Radikalisme di Internet". Jurnal Agama dan Lintas Budaya. Vol. 1, No. 2, (2017).

Faubion James. 1994.

Aesthetics, Method, And Epistemology. New York: The New Press.

Hasan Noorhaidi. 2016. Laskar Jihad, Islam, Militancy and the Quest for Identity in Post New Order Indonesia. New York: Cornell Southeast Asia Program.

Hasan Noorhaidi. 2019. "Tantangan Islam Politik dan Krisis Legitimasi Ulama," dalam Noorhaidi Hasan, Ulama dan Negara-Bangsa Membaca Masa Depan Politik Islam di Indonesia. Yogyakarta: PusPIDep. Muzakki Akh. "Islam as a Symbolic Commodity: Transmitting and

Consuming Islam Through Public Sermons in Indonesia," dalam Pattana Kitiarsa (ed.), Religious 
Commodifications in Asia: Marketing Gods (London dan New York: Routledge, 2008).

Mupida Siti dan Nisai Shalihati Khoirin. "Dakwah by The Pen: Salim A. Fillah see Authority in Pro U Media”. Interdisciplinary Journal of Communication. Vol. 4, No. 1 (2019).

Mupida

Siti.

http://swarakampus.com/web/2018/1 0/15/berita-hoax-memecah-belahmasyarakat/\#

Mupida

Siti.

http://swarakampus.com/web/2018/1

1/02/agama-dan-media-baru/ Mupida

Siti.

http://swarakampus.com/web/2019/0

9/29/peran-politik-kampus/

Nisa Jakiatin. "Resolusi

Konflik dalam Perspektif

Komunikasi".Jurnal Sosial dan

Budaya Syar" $i$. Vol. II, No. 1 (2015).

Najib Burhani Ahmad.

"Pluralism, Liberalism and Islamism:

Religious Outlook of

Muhammadiyah". Studia Islamika.

Vol. 25, No. 3 (2018).

IPAC Report No 56, (2019),

"The Ongoing Problem of Pro-ISIS Cells in Indonesia".

Qodir Zuly. "Gerakan Salafi Radikal dalam Konteks Islam Indonesia: Tinjauan Sejarah", ISLAMIKA. Vol. 1, No. 8 (2008).
Syahputra Iswandi. "Media Sosial dan Prospek Muslim Kosmopolitan; Konstruksi dan Peran Masyarakat Siber Pada Aksi Bela Islam". Jurnal Komunikasi Islam. Vol. 08, No. 01, (2018).

Setiadi Elly M. \&Kolip Usman. 2013. Pengantar Sosiologi Politik.Jakarta: Prenada Media Group.

Van Bruinessen Martin, ed. 2013. Contemporary Development in Indonesian Islam, Explain the "Conservative Turn". Singapore: Institute of Southeast Asian Studies.

Wildan Muhammad. "The Nature of Radical Islamic Groups in Solo". Journal of Indonesia Islam. Vol. 07, No. 01, (2013).

Wildan Muhammad. "Aksi Damai 411-212 dan Kesalehan Polpuler, dan Identitas Muslim Perkotaan di Indonesia".Maarif Institute for Culture and Humanity. Vol. 11. No 2, (2016).

Wahid Din. "Kembalinya Konservatisme Islam Indonesia". Studia Islamika. Vol. 21, No, 2, (2014).

Waid, Ahfa. 2017. NasihatNasihat Keseharian Gus Dur, Gus Mus, dan Cak Nun. Yogyakarta: DIVA Press. 